\title{
Geoproduct potential analysis based on the example of the GEOsfera Ecological and Geological Education Center in Jaworzno
}

\author{
Analiza potencjału geoproduktu \\ na przykładzie Ośrodka Edukacji Ekologiczno-Geologicznej GEOsfera w Jaworznie
}

\author{
Barbara Bieniek ${ }^{1,2, a}$, Alina Kordysh ${ }^{1,2, b}$, Mateusz Mirosławski ${ }^{1,2, c}$, \\ Katarzyna Nowak ${ }^{1,3, d}$, Kacper Sękowski ${ }^{1,2, e}$, Edyta Sierka ${ }^{1,3, f, *}$ \\ ${ }^{1}$ College of Individual Interdisciplinary Studies of the University of Silesia in Katowice, Bankowa 12, 40-007 Katowice \\ ${ }^{2}$ Faculty of Social Sciences, Bankowa 11, 40-007 Katowice \\ ${ }^{3}$ Faculty of Natural Sciences, Będzińska 60, 41-205 Sosnowiec; Jagiellońska 28, 40-032 Katowice

 \\ ekaspian313@gmail.com; fedyta.sierka@us.edu.pl
}


Article history:

Received: 28 September 2020

Accepted: 12 December 2020

Available online: 17 February 2021

(C) 2019 Authors. This is an open access publication, which can be used, distributed and reproduced in any medium according to the Creative Commons CC-BY 4.0 License requiring that the original work has been properly cited.

\begin{abstract}
At the time of discovering and exposing the scientific and educational potential of areas where mineral resources were exploited in the past, they have become a significant element in tourism elements. In the presented paper, the potential of the GEOsfera Ecological and Geological Education Centre in Jaworzno as a geoproduct was analysed. In the first part of the study, based on the published works and consultations with experts, the "geoproduct" was defined. Then the area, where the GEOsphere is located, was characterized. Its geology, the natural world, the way of land development and the promotion of geo-attractions located in this area are described. In the next stage, an analysis of the opinions of users regarding their perception of the GEOsphere was carried out. For this purpose, evaluations posted on social media and the collected survey results were used. As shown by the results, the majority of users of the GEOsfera are residents of Jaworzno - $63 \%$ of the respondents. The importance of the GEOsphere as an educational centre was indicated by $22 \%$ of visitors. About $5 \%$ of the respondents mentioned learning and obtaining information from the descriptions placed next to the exhibits in the centre. $93 \%$ of respondents recognised the graduation tower as the greatest attraction of the GEOsphere. Over $92 \%$ of people noticed the recreational role of the GEOsphere. $81 \%$ of users declared that they were satisfied with their visit to the GEOsphere. More than half of the respondents (56\%) visited the GEOsfera with their family. A significant part of respondents (42\%), pointed to the role of environmental protection, which is extremely important from the point of view of geoproducts'design. The respondents also indicated that the GEOsphere has numerous geological, natural and educational functions and protects and promotes the geological heritage of the region.
\end{abstract}

Keywords: geo-attractions, geological education, natural potential, limestone quarry, Jaworznickie Hills

Treść: $W$ dobie odkrywania i eksponowania potencjału naukowego i edukacyjnego terenów, na których w przeszłości prowadzono eksploatację surowców, stają się one znaczacymi obiektami turystycznymi. W prezentowanej pracy dokonano analizy potencjatu Centrum Edukacji Ekologiczno-Geologicznej GEOsfera w Jaworznie, zlokalizowanego na terenie wyrobiska surowców skalnych, jako geoproduktu. W pierwszej części opracowania, opierając się na dostępnych pracach publikowanych i konsultacjach z ekspertami, zdefiniowano „geoprodukt” oraz określono kryteria, jakie powinien spetniać. Następnie opisano teren, na którym zlokalizowana jest GEOsfera, uwzględniając geologię, elementy przyrody ożywionej oraz sposób zagospodarowania terenu i promowania geoatrakcji, które się tam znajdują. Na kolejnym etapie przeprowadzono analize opinii użytkowników w zakresie postrzegania przez nich GEOsfery. Do tego celu wykorzystano oceny 
zamieszczone w mediach spotecznościowych i zgromadzone wyniki badań ankietowych. Wykazały one, że większość spośród badanych u̇̇ytkowników GEOsfery to mieszkańcy Jaworzna, którzy stanowili 63\% ankietowanych. Znaczenie GEOsfery jako istotnego ośrodka edukacyjnego wskazało 22\% odwiedzających. Około 5\% pytanych doceniło uczenie się i pozyskiwanie informacji z opisów umieszczonych na tablicach obok eksponatów na terenie ośrodka. Jako największa atrakcję terenu GEOsfery 93\% ankietowanych wskazało tężnię solankowa. Ponad 92\% respondentów dostrzegło rekreacyjna rolę GEOsfery i dogodne warunki do aktywnego spędzania czasu. $81 \%$ badanych zadeklarowato zadowolenie z wizyty. Ponad polowa respondentów (56\%) odwiedzita GEOsferę z rodzina. Znaczna część ankietowanych (42\%) zwróciła uwage na znaczenie ochrony środowiska w funkcjonowaniu GEOsfery, co jest niezwykle ważna informacja przydatna podczas projektowania geoproduktu. Użytkownicy, którzy wzięli udziat w badaniu, wskazali również, że GEOsfera ma liczne walory geologiczne, przyrodnicze i edukacyjne oraz chroni i promuje dziedzictwo geologiczne regionu.

Słowa kluczowe: geoatrakcje, edukacja geologiczna, potencjał przyrodniczy, kamieniołom wapieni triasowych, Pagóry Jaworznickie

\section{Introduction}

More and more often, areas where the extraction of raw rock materials has ended are used as tourist attractions, combining education with leisure (Woźniak et al., 2011). The Sadowa Góra quarry in Jaworzno is a good example of such a transformation, where environmental potential has been adapted for the purpose of education, mainly in geology, but also in the field of biological sciences. Post-mining areas, often with a significant potential of preserved natural qualities (fossils, geological formations, etc.), as a result of human industrial activity, can be used to create facilities, which are attractive for tourists and are able to function as commercial entities.

The aim of this study is to analyse the tourism potential of the quarry area turned into Centre for Ecological and Geological Education - GEOsfera, as a geoproduct.

What is a geoproduct? A geoproduct, according to Michał Poros (2014), the director of the Kielce Geopark, is defined as a popularization tool for the product of Earth sciences. It is a post-exploitation area, an artefact of a past state or activity that connects all interested communities, the academics, specialists, experts in the subject, and people involved in the dissemination of knowledge. A geoproduct is correlated with the goals of local governments focused on development and education. In terms of geology, it is the uncovering of an important place in this respect, e.g. a post-mining area, which must, however, be identifiable with a tourism event promoted under a specific name. Contrary to the essence of the geoproduct, it does not have to be related to geology as such. It presupposes a greater contribution from people and history rather than only from the presence of nature in itself. Often, it refers only to historical memory, being attached to a place that builds the identity of the local community.

According to the UNESCO definition (UNESCO Geoparks Programme... 1999), "geoproducts are innovative artisanal products that are associated with geology". In the opinion of Farsani et al. (2012), a geoproduct should be made from locally sourced products, while being a symbol of the geological (or geomorphological) heritage of the area. It should be an educational tool, as well as a commercial product. In accordance with the idea of sustainable development, a geoproduct must be environmentally friendly and should combine local traditions with scientific elements.

Dryglas \& Miśkiewicz (2014) proposed the classification of geoproducts. The basic groups of geoproducts include:

- objects, e.g. geotouristic guides, handicrafts (geo-cosmetics, geo-jewellery);

- locations, e.g. mining facilities, lapidary workshops;

- events, e.g. mineral exchanges, geological picnics, geo-conferences;

- services, e.g. geo-educational, geo-sales, geo-medical (lithotherapy).

In addition, complex geoproducts such as:

- events, e.g. field games (Geocaching);

- paths, e.g. educational paths;

- areas, e.g. national and UNESCO geoparks, mineral springs.

Based on the information above, a "geoproduct can be defined as any object, institution, or an event aimed at promoting the geological heritage of a specific area, related to the concepts of earth sciences and life sciences, used for commercial and educational purposes, and inherently environmentally friendly". A geoproduct is directly related to geotourism focused on learning about geological facilities and processes. Through direct contract, a geoproduct allows one to experience sensual and aesthetic impressions. Geotourism utilises the results of basic geological research for practical purposes and is closely related to environmental protection (Ścibisz-Kosanowska et al., 2013).

\section{Study methods and characteristics of the research subject}

Material used in the analysis was collected from the available expert studies and published papers. Results were obtained also from questionnaires prepared by the authors. 
The Centre for Ecological and Geological Education GEOsfera in Jaworzono was adopted as the research subject.

GEOsfera is the facility with the total 8 ha of the landscaped area, established on the site of a former dolomite quarry (Fig. 1). Located between Jaworzno city centre and the Sand Mountain, on premises Sadowa Góra. During the Triassic Era, 230 million years ago, this area was occupied by a shallow and warm sea, inhabited by a swimming prehistoric lizard - the Nothosaurus. With time, some dead remains of bivalves, brachiopods and echinoderms settled on the seabed.



Fig. 1. Localisation of the Centre for Ecological and Geological Education GEOsfera in Jaworzono

Until 1980, limestones and dolomites were mined in this area for the needs of the cement industry. After the raw rock materials were exploited, attempts were made to cover the quarry with waste. However, thanks to the involvement of Jaworzno authorities and experts in the field of geology and zoology, who identified the natural, mainly geological potential of the area, it was decided in 2014 that the GEOsfera will be established in the quarry. Funds were obtained for this purpose from the European Regional Development Fund under the Regional Operational Programme of the Śląskie Voivodeship for the years 2007 - 2013. The current GEOsfera has an extensive infrastructure, i.e. a ripple marks exhibition pavilion, reconstruction of Triassic vertebrate habitats, a graduation tower, a "geological window" and an educational trail with information signs.

The Sadowa Góra quarry is located within the Garb Jaworznicki highland region (Kurek et al., 1994; Jochemczyk et al., 2004; Tokarska-Guzik et al., 2012), which, along with the Garb Ciężkowicki region is a part of the Jaworznickie Pagóry range. The region borders from the East with a Pleistocene denudation plain, which is filled with sands and gravels dating back to the Odra glaciation (Tokarska-Guzik et al., 2012). The hills of Jaworznickie Pagóry are inliers. They consist of monoclinally arranged carbonate Triassic formations (Kurek et al., 1994). Sadowa Góra is an old excavation site where mainly marly conglomerates of the upper Gogolin Formation were excavated (Nita \& Bradziński, 2008 after: Woźniak \& Krzeczyńska, 2014). The Gogolin Formation developed in the Triassic and is divided into the lower (older) and the upper (younger). The lower Gogolin Formation consists of carbonate rocks: limestones, conglomerates with a carbonate binder and marls. In the lowest part of its profile, the Gogolin Formation consists of: micrite, fine-detritic, medium and thickbed limestones, containing numerous fragments of crinoids. Their main species is Dadocrinus kunischi (Kurek et al., 1994). Crinoids belong to the echinoderms family. Their fully preserved frames, including the crown, are a rare find, because usually the dead flower crumbles. You can find many trochites at the GEOsfera (Woźniak \& Krzeczyńska, 2014). They are single rings that build the daylily stem. In their glory days, when they lived static lives, crinoids formed so-called lily meadows. Abundant accumulations of trochites are the building blocks of crinoid limestones. Crinoids fragments are accompanied by numerous bivalves, predominantly the Pecten discites, as well as Plagiostoma striatum species. Marly limestones with a wavy roof and bottom reside above the crinoid limestones. The lower part of the Gogolin Formation consists of some open sea sediments, associated with the first transgression of this period. Dark yellow dolomitic cellular limestones are at the bottom of the lower part of the Gogolin Formation. They are a relic of evaporites formed as a result of gradual regression of the sea basin (Woźniak et al., 2010).

The upper part of the Gogolin Formation begins with conglomerate and intra-formation limestones, in which we can find pebbles of micrite and marly limestones from the lower layers of the formation. Crinoid limestone containing bivalves (Lima striata Goldfuss) is the binder here along with fragments of reptile bones (Kurek et al., 1994). The highest part of the Gogolin Formation consists of micrite and sparite limestones. This layer contains two levels with a wavy texture - that is the $2^{\text {nd }}$ and $3^{\text {rd }}$ wavy limestone. The upper part of the Gogolin Formation displays a record of a sea transgression that caused the emergence of Tethys Ocean fauna in the Germanic Basin (Woźniak et al., 2010). The thickness of the Gogolin Formation ranges from 25 to 30 meters. Above the Gogolin Formation, the Diplopora-bearing layers can be found, followed by Tarnowice Beds, which end with middle Muschelkalk limestones. The upper Muschelkalk limestones is composed of the Boruszowice Beds, which, just like the Tarnowice Beds, are made of micrite and oolite dolomites with sandstone interbedding (Kurek et al., 1994; Jochemczyk et al., 2004; Woźniak et al., 2010). 
The Szczakowa Cement Plant ended production in Jaworzno in 1999. It was the chief recipient of raw rock materials, so mining stopped as well and excavation site walls were left exposed. One can clearly observe the sequence of rock layers of the Gogolin Formation in the profile of the quarry walls. Beginning with crinoid limestone, $1^{\text {st }}$ wavy limestone occur, then intra- to the formation conglomerate and $2^{\text {nd }}$ wavy limestone occur finally (Markowiak, 2014). In the rocks, we can find numerous fossils, ichnofossils, including the aforementioned crinoid trochites. The wall of the GEOsfera quarry is a record of the Germanic Sea that filled this area 225-210 million years ago. It was an epicontinental sea (with a maximum depth of 100 meters, 50-60 m in today's Jaworzno city limits), well oxygenated, in which predatory reptiles thrived. Reptiles are represented at GEOsfera by the fish-eating Nothosaurus, which is classified as a primitive fin-lizard (Markowiak, 2014). The length of their bodies could exceed four meters (Surmik, 2013). Apart from the "false lizard", the ichthyosaurs and posterodontons also probably lived at Sadowa Góra (Woźniak \& Krzeczyńska, 2014). The GEOsfera Jaworzno can boast of the presence of mega ripplemarks on its grounds (Fig. 2). These are numerous, regular furrows separated by gutters. These wrinkles flow in the North-South direction. Their size and amplitude $(10-35 \mathrm{~cm})$ suggest that they are the result of oscillatory waves in the declining phase of tropical hurricanes (Markowiak, 2014; Woźniak \& Krzeczyńska, 2014). In geology, objects of this type are used to reconstruct palaeoenvironments.
The above-mentioned crinoids are examples of living fossils, but only those species that have retained the stem are present.

The area of the centre in question can boast of a unique wealth of Triassic rocks, but also a stunning display of animated nature, i.e. flora and fauna, for which the quarry has provided favourable conditions for development. The walls of the excavation are cliffs and there are numerous depressions and elevations at the bottom. The soil variations are at the stage of initial rendzinas with varying levels of humus, carbonate rocks and moisture.

Diverse habitat conditions allowed for the formation of a mosaic of plant communities in this area, from places covered with vegetation consisting of forests in initial stages of development, through shrubs, grasslands and meadows to typically ruderal areas (Fig. 3). In the quarry itself and in its immediate vicinity, 433 species of vascular plants were found (Szendera et al., 2016). Characteristic elements of this area are thickets of shrubs including blackthorn (Prunus spinosa), European buckthorn (Rhamnus cathartica) and single-necked hawthorn (Crataegus monogyna). Undergrowth and small biogroups of trees are mainly composed of Scots pine (Pinus sylvestris) and warty birch trees (Betula pendu$l a$ ), species that disseminate thanks to the wind. Slopes with sliding layers of weathered limestone are covered mainly with species of blackberry (Rubus sp.), but also with spontaneous growth of light-seeded trees such as Scots pine, silver birch and willow trees.



Fig. 2. Mega ripplemarks. Photo E. Sierka 


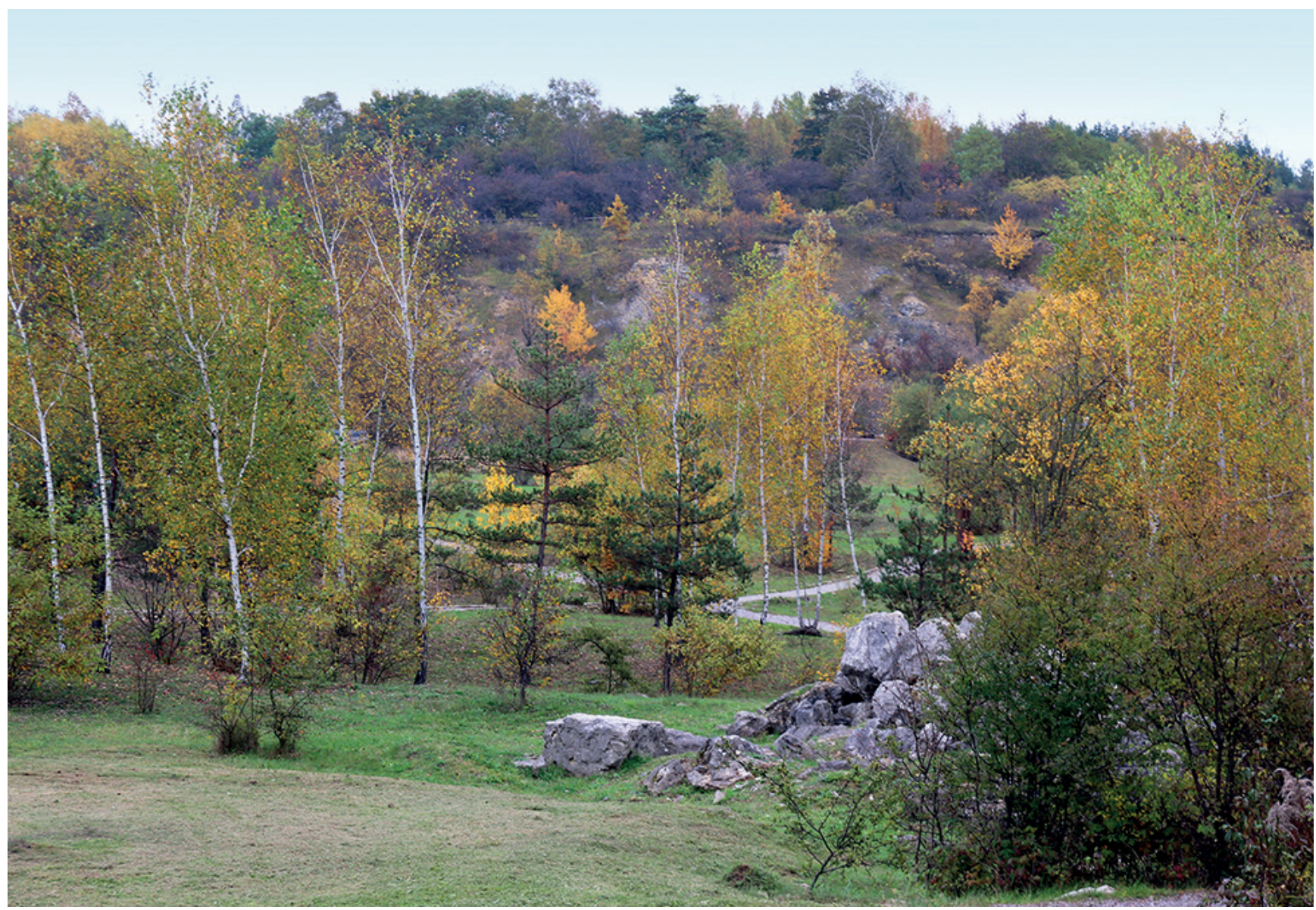

Fig. 3. Quarry walls with spontaneously encroaching vegetation. Photo E. Sierka

Xerothermic grasslands are an inextricable element of limestone areas at GEOsfera. These thermophilic communities consist of the Carthusian pink (Dianthus carthusianorum), the spiny restharrow (Ononis spinosa), and many others. In places where the terrain is almost flat, sandy grasslands develop fragmentarily on the sandy ground. At GEOsfera, these communities are mainly formed by dicotyledonous plants, i.e. sand thyme (Thymus serpyllum), sea thrift (Armeria maritima), and field chickweed (Cerastium arvense). Meadow communities also develop spontaneously in moderately humid places. Where the permeability of the substrate is lower, e.g. at ripple marks or depressions, temporary stagnant water gathers, thus eliminating species that do not prefer stagnant water.

Simultaneously vegetation from adjacent areas appears in the fissures where rocks are weathering. On the grounds of the Centre for Ecological and Geological Education, many habitats have been established by man. These include a water reservoir with rush vegetation consisting of lakeshore bulrush (Schoenoplectus lacustris), the European water-plantain (Alisma plantago-aquatica), and the broadleaf cattail (Typha latifolia), as well as submerged vegetation including the spiked water-milfoil (Myriophylum spicatum). As part of the
"BioGalmany" project, the calamine plants area was created with plant species associated with this very specific habitat. The area also includes sensory gardens that can be perceived with all senses, i.e. sight, smell, touch, hearing and taste.

The resulting wealth of plant species also indicates the diversity of other organisms. The GEOsfera faunal inventory (Inwentaryzacja przyrodnicza... 2017) showed the presence of 282 different species of animals from the groups: annelids (1), molluscs (10), crustaceans (2), trichomonads (13), insects (165), centipedes (3), amphibians (7), reptiles (4), birds (60), mammals (17). The quarry itself is a natural terrain 'trap' for smaller fauna specimens living in its vicinity, integrated into the local landscape. Some animals move to the GEOsfera area or its vicinity, while others are blown over from neighbouring biotopes, open areas and forests, as well as the surrounding Pagóry Jaworznickie hills covered with diverse plant systems. In addition, the semi-open quarry area is located on the route of local animals migrating between various types of biotopes, from near and far in the vicinity, including larger forest complexes (Inwentaryzacja przyrodnicza... 2017). Numerous species of butterflies are associated with limestone areas, such as the chalkhill blue (Polyommatus coridon). 
A vertebrate species associated with wetland habitats is e.g. the European tree frog (Hyla arborea). This species leads a land-water lifestyle. It can climb trees and begins its activity only at dusk. There are also animals only temporarily living at the GEOsfera, e.g. using the quarry area as an ecological corridor in their migration. Within the OEEG GEOsfera, one can find the Field Research Station of the University of Silesia in Katowice - BIOGEO, where students learn about the diversity of life forms in this area.

Closed quarries are experiencing a renaissance nowadays, often adapted for recreational purposes and events for minerals and fossils enthusiasts. As a result, geotourism is on the rise, encouraging tourists to explore in depth the regions they visit and offering them an opportunity to learn about the natural history of our planet. The GEOsfera in Jaworzno is a good example of an attractive geotourism site (Chybiorz \& Kowalska, 2017). The main idea behind the creation of GEOsfera is the large-scale promotion of the riches of the natural world. In the extensive sensory park created here, one can see over forty thousand plants. It is a place where, apart from recreation and tourism, the educational offer reaches far beyond the limits of academic theory. The main concepts behind the establishment of the Centre focus on the inextricable bond between all elements of the natural environment, as well as on showing the constant changes in the plant and animal world. One of the main goals of the Centre is nature education, based on acquiring knowledge and skills through experience and shaping desirable environmental attitudes.

Installations at GEOsfera with an especially large potential in terms of geotourism include, among others, reconstructions of the Triassic four-legged land animals. At GEOsfera a small pavilion was built for the purpose of showcasing ripple marks, which were most probably created as a result of a gigantic tsunami caused by an earthquake. Right next to the pavilion, there are mega ripplemarks, i.e. huge fossilized wave marks (Fig. 3). The geological history information has been placed on educational billboards and is presented at numerous exhibitions that bring the history of the Triassic period to life. In addition, currently the centre organizes nearly thirty different thematic activities available for free to groups of tourists.

In addition to being an educational space, the GEOsfera also offers recreational facilities. Walking routes, viewpoints, a graduation tower, a barbecue site, a small amphitheatre, a playground, a didactic room, a pond, a seasonal clock, a weather station, a moorland and a sensory garden are all located on an area of 20 acres.

Admission to the premises is free, and lighting available 24 hours allows guests to visit without time restraints. The direct safety measures at the facility include a video surveillance system. There is a small car park for guests arriving by car. Public transport to and from the city centre is also available. The GEOsfera is a place for those who are interested in history and excavations, as well as for those who seek peace and relaxation, which is extremely important in the densely populated Silesian conurbation.

\section{Results}

The GEOsfera is present in social media via Facebook and Trip Advisor. Since the creation of the profile in 2014, 9161 people have liked the GEOsfera page on Facebook, which is a moderate result when you consider that the GEOsfera has about 10,000 visitors annually. Announcements about site modernisation, educational events, etc. are published via Facebook. The popularity of posts published for two months (May-June 2019) ranged from 5 to 322 likes per post.

The average rating of the facility, out of 200 opinions expressed on Facebook, is 4.7 on a five-point scale. In addition, 60 people posted comments to GEOsfera, in which they indicated the following advantages of the facility presenting in Fig. 4.



37.3



Fig. 4. Opinions evaluating GEOsfera park in Jaworzno on basis of Facebook portal

The centre in Jaworzno also has a profile on Trip Advisor, where the average rating from 31 user ratings is $4 / 5$. Written opinions were expressed by 26 users, in which they indicated the following advantages of the facility in Figure 5.

Opinions expressed by internet users show that GEOsfera is primarily perceived as a place for relaxation, where you can go for walks with children. On Facebook, only a small $(6.7 \%)$ group of visitors mentioned the educational or natural value of the facility. Almost a quarter of commenting users $(23 \%)$ emphasized the value of these elements on Trip Advisor, but still most (65\%) visitors considered the GEOsfera primarily as a good place to visit with children. 




Fig. 5. Opinions evaluating GEOsfera park in Jaworzno on basis of Trip Advisor portal

A poll consisting of 13 questions in a questionnaire was conducted on a sample of 100 people (61 women, 39 men) at the centre. The results show that:

- Most respondents (63\%) were residents of the city Jaworzno. Of the remaining $37 \%$, four people declared that they live in the countryside.

- Most of GEOsfera visitors found out about it from friends $(53 \%)$ or learned about it on the Internet $(26 \%)$. Only $5 \%$ of visitors found information about the GEOsfera in the press. This observation most probably indicates that the GEOsfera is not present nearly enough in either traditional or social media. Only $8 \%$ of respondents came upon the facility while driving or walking by, and $2 \%$ of the respondents found out about it from regional television.

- The most frequently declared purpose of visiting the GEOsfera was taking a walk in the open air $(71 \%$ of respondents). The second most frequent purpose of a visit to GEOsfera was leisure (55\%), and the third providing children with something engaging and fun (30\%). Education was mentioned by only $22 \%$ of visitors. Only $2 \%$ of people declared taking advantage of the graduation tower as the purpose of their visit. At the very bottom of the list, $1 \%$ of visitors indicated their professional duties as a reason to visit, tied with "curiosity", also at $1 \%$.

- In response to an open-ended question about activities undertaken in the park, $90 \%$ of people mentioned walking, $21 \%$ inhalation, $5 \%$ viewing the objects (especially dinosaur reconstructions). Only $5 \%$ of people also mentioned learning and obtaining information from descriptions next to the exhibits, and $2 \%$ of people indicated cycling.

- The brine graduation tower was considered the most attractive facility at the GEOsfera (as many as $93 \%$ of respondents considered this facility as exceptionally attractive). The sensory garden was second (45\%). In turn, $33 \%$ of people found the dinosaur reconstructions very appealing, $23 \%$ mentioned the bonfire place, and only $15 \%$ came to visit to see the calamine plants. The playground was mentioned in a few answers.

- Almost half, i.e. $44 \%$ of the respondents, declared that they spent 31-60 minutes at the GEOsfera, while 25\% spent $61-120$ minutes, $23 \%$ spent over two hours, and only $8 \%$ spent no more than 30 minutes at GEOsfera.

- Over $92 \%$ of respondents recognise the recreational role of the GEOsfera, which is in line with the most frequently declared purpose of visits to the GEOsfera - walking and leisure. Interestingly, the educational role was in second place ( $81 \%$ ), although only $22 \%$ of respondents declared education as the purpose of their visit. This points to the fact that the educational role of the GEOsfera is widely recognised, but it can be better utilised to build the potential of the GEOsfera as geoproduct. As many as $71 \%$ of respondents believe that the GEOsfera effectively promotes the region, and $42 \%$ see its contribution to environmental protection. The health role was also emphasised, i.e. supporting the healing process for patients $(2 \%)$.

- $81 \%$ of respondents declared they were satisfied with their visit to GEOsfera, 15\% were not fully satisfied, and $4 \%$ were undecided on the matter.

- In the surveyed group, $37 \%$ of respondents believe GEOsfera could benefit from a number of improvements, and the suggestions were as follows: four people pointed to the lack of places to eat, two people did not like the gravel paths, two visitors indicated the need to take better care of the vegetation, and another two recommended building a fountain. Some expressed the need for more activities for children, including multimedia. Some pointed out that the area could be cleaner or that the dinosaur models could be bigger.

- More than half of the respondents (56\%) visited the GEOsfera with their families, $26 \%$ came with friends, and $16 \%$ with a partner. $5 \%$ visited the GEOsfera on a school trip, and $4 \%$ came alone. The results show that the GEOsfera is a family establishment. This is important in the context of possible changes that may be introduced (e.g. making it more attractive to children).

In general, the GEOsfera is viewed positively by visitors. However, knowledge about the GEOsfera is distributed mainly through word of mouth, less so through the media. This indicates the need for better publicity at the centre. Some aspects of the GEOsfera, when defined as a geoproduct, are noticed and perceived as important by visitors, especially 
its educational role. Several hypotheses can be made about this state of affairs. One of them is the low appeal of educational objects, which was indicated by respondents in the open question. A significant number of respondents (42\%) noticed the environmental protection role, which is extremely important from the point of view designing a geoproduct. Perhaps the environmental role was not emphasised strongly enough by the exhibits and their descriptions in the park. A facility of great importance for the GEOsfera is the brine graduation tower, which draws visitors who are not interested in geology, nature or the educational offer of the Centre, but in improving their health.

GEOsfera as a geoproduct. In light of the definition of a geoproducts proposed by Dryglas \& Miśkiewicz (2014), the GEOsfera in Jaworzno offers its visitors numerous geo-attractions, which are geoproducts. The facility hosts mineral exchanges that fall under the "events" category. There are also "facilities" on the site: a lapidarium, a graduation tower, a sensory garden and reconstructed mining facilities. It is important to remember that the Centre itself used to be a mining facility. In the "services" category, geoeducation is at the top of the list. Moreover, the GEOsfera offers more complex geoproducts: recreational games such as Geocaching and educational trails.

After analysing the GEOsfera Centre in terms of the definition of a geoproduct adopted for the purposes of this work, it was established that the GEOsfera fulfils all the requirements to be categorized as such. This is achieved thanks to:

- the development of the area for the purposes of tourism and education protecting the geological heritage of the region;
- promotional activities provide publicity for the region and its heritage;

- exhibitions, events and educational trails at the GEOsfera fulfil its educational role;

- thanks to its aesthetic merits and facilities such as the graduation tower, the GEOsfera is developing its commercial and geotouristic potential;

- the growing number of visitors (only $40 \%$ are not residents of Jaworzno) proves the need for such facilities;

- the commercial aspect resulting from the definition of a geoproduct is not fully realised at the GEOsfera. Rather it relies on the durability of the project, as part of which the GEOsfera was created.

\section{Recommendations and summary}

The GEOsfera Ecological and Geological Education Centre in Jaworzno meets the criteria of a geoproduct, meaning that it fulfills both the aesthetic and didactic expectations and is of value to the citizens of Jaworzno and tourists.

However, in order to strengthen its rank, it is worth considering:

- increasing the number and visibility of signs indicating the location of the GEOsfera;

- taking into account the presence of disabled people e.g. modifying fragments of gravel paths that make it difficult to move around on bikes or wheelchairs;

- better display of fossils and Nothosaurus models (Fig. 6), whose information boards should be larger and in a more visible places.



Fig. 6. Nothosaurus models at GEOsfera. Photo E. Sierka 
The centre, despite the huge local and even national potential (as evidenced by the top award of the Ministry of the Environment "Geology 2018") and the multiple elements that emerged during and after its exploitation, does not meet the criteria of being a geopark. The Jaworzno facility rather fits into the idea of geosites (Chybiorz et al., 2015) and is included in the Central Register of Geosites run by the PGI-NRI (Polish Geological Institute - National Research Institute).

The GEOsfera as a cultural and ecological institution appears to be a well-run project, created thanks to people involved in strengthening the tourist appeal of the local natural environment. A product has been created that is a family-friendly, allowing for better contact with nature, surrounded by the remains of a historic quarry with geological formations. It is also a very important area for the integration of Jaworzno residents.

\section{Acknowledgments}

The authors of this paper would like to thank:

Mrs. Agnieszka Chećko, director of the Centre for Ecological and Geological Education GEOsfera in Jaworzno, and Mr. Paweł Woźniak from PGI-NRI Sosnowiec Branch, for consultations and substantive support.

The project was realised as a part of the module for finding solutions to heterogeneous problems and was financed by the College of Individual Interdisciplinary Studies of the University of Silesia in Katowice in 2019.

\section{References}

Chybiorz R. \& Kowalska M., 2017. Inwentaryzacja i ocena atrakcyjności geostanowisk województwa śląskiego. Przegląd Geologiczny, 65(6): 365-374.

Chybiorz R., Babczyńska-Sendek B., Rostański A., Gorczyca J., Pasierbiński A., Fojcik B., Nowak T., Bzdęga K., Woźniak G., Strzelec M., Krodkiewska M., Bula R., Urbisz A., Sierka E., Jędrzejczyk-Korycińska M., Błońska A., Bardziński W., Kurowska E., Nita J., Waga J.M., Orczewska A. \& Tokarska-Guzik B., 2015. Dane o różnorodności biologicznej i georóżnorodności - Geostanowiska. In: Tokarska-Guzik B., Chybiorz R. \& Parusel J.B. (red.), Baza danych przestrzennych $w$ zarzadzaniu zasobami środowiska przyrodniczego województwa śląskiego. Uniwersytet Śląski w Katowicach: 108-114.

Dryglas D. \& Miśkiewicz K., 2014. Construction of the geotourism product structure on the example of Poland. In: $14^{\text {th }}$ GeoConference on Ecology, Economics, Education and Legislation. International Multidisciplinary Scientific Geoconferences, 5(2): 155-162.

Farsani N.T., Coelho C., Costa C. \& Neto de Carvalho C. (eds.), 2012. Geoparks \& Geotourism - new approaches to sustainability for the $21^{\text {st }}$ Century. Brown Walker Press, Boca Raton.

Inwentaryzacja przyrodnicza fauny Ośrodka Edukacji Ekologiczno-Geologicznej w Jaworznie, 2017. Envirex. Usługi Środowiskowe i Edukacja [unpublished].

Jochemczyk L., Krieger W., Lis J., Olszewska K., Pasieczna A., Preidl M., Strzemińska K., Wołkowicz S. \& Strzelecki R., 2004. Objaśnienia do mapy geośrodowiskowej Polski 1:50000, Arkusz Jaworzno, Państwowy Instytut Geologiczny.

Kurek S., Paszkowski M. \& Preidl M., 1994. Objaśnienia do szczegótowej mapy geologicznej Polski 1:50000, Arkusz Jaworzno (944), Państwowy Instytut Geologiczny.

Markowiak M., 2014. Karta dokumentacyjna geostanowiska - 007390: „, GEOsfera w Jaworznie”, Centralny Rejestr Geostanowisk Polski PIG-PIB, http://geostanowiska.pgi.gov.pl. [accessed: 2020.10.27]

Nita J., Bardziński W., 2008. Ogólna inwentaryzacja walorów geologicznych Kamieniołomu Sadowa Góra na terenie miasta Jaworzna (z opracowaniem kopalnych form dna morskiego - megariplemarków). Urząd Miasta Jaworzna [unpublished] after: Woźniak P.
\& Krzeczyńska M., 2014. Kamieniołom Sadowa Góra w Jaworznie - przyszłość pod znakiem GEOsfery!. Przegląd Geologiczny, 62(10/1): 510-513.

Poros M., 2014. Georóżnorodność w architekturze - wykorzystanie lokalnych surowców skalnych w architekturze użytkowej na obszarze istniejących i projektowanych geoparków europejskich. Przegląd Geologiczny, 62(3): 151-155.

Surmik D., 2013. Triasowe gady morskie w Polsce. In: Machalski M. (red.), Rocznik Muzeum Ewolucji Instytutu Paleobiologii PAN, 5: 9-16.

Szendera W., 2016. Inwentaryzacja przyrodnicza terenu kamieniołomu Sadowa Góra w Jaworznie, 79 [unpublished].

Ścibisz-Kosanowska M., Kowalska M. \& Szrek P., 2013. Geoturystyka w regionach turystycznych Polski południowo-wschodniejprzystosowanie obiektów geoturystycznych na potrzeby turystyki zrównoważonej. Zeszyty Naukowe Turystyka i Rekreacja, 11(1): 67-82.

Tokarska-Guzik B., Rostański A., Gorczyca J., Herczek A. \& Dulias R., 2012. Waloryzacja przyrodnicza miasta Jaworzna, Zakład Badawczo-Usługowy "EKOS". https:/www.um.jaworzno.pl/pl/natura/ przyroda_i_ekologia/39/waloryzacja_przyrodnicza_miasta.html [accessed: 2020.10.27].

UNESCO Geoparks Programme: a new initiative to promote a global network of geoparks safeguarding and developing selected areas having significant geological features, 1999: 156 EX/11 REV. https://unesdoc.unesco.org/ark:/48223/pf0000115177 [accessed: 2020.10.27].

Woźniak P. \& Krzeczyńska M., 2014. Kamieniołom Sadowa Góra w Jaworznie - przyszłość pod znakiem GEOsfery!. Przegląd Geologiczny, 62(10/1): 510-513.

Woźniak P., Sikora R., Lasoń K., Markowiak M., Haisig J., Szulc J. \& Hagdorn H., 2010. Geopark Góra św. Anny-udokumentowanie i propozycja jego ochrony, PIG-PIB Oddział Górnośląski im. St. Doktorowicza-Hrebnickiego. https://www.pgi.gov.pl/docman-tree/oddzialgornoslaski/2071-gora-sw-anny-opracowanie/file.html [accessed: 2020.10.27].

Woźniak P., Sikora R., Lasoń K., Markowiak M., Haisig J., Szulc J. \& Hagdorn H., 2011. Geopark Góra Św. Anny - „król-tułacz” wrócił na stolicę!. Przegląd Geologiczny, 59(4): 291-310. 